\title{
THE ROLE OF RELIGIOUS NORMS ON SELECTING THE ISLAMIC BANK
}

\author{
Hardius Usman ${ }^{1}$
}

\begin{abstract}
The Role of Religious Norm in Selection of Islamic Banking. The aims of this study are to examine Muslim's religious norms regarding to their belief on the law of the prohibition of bank interest, and to investigate the effect of religius norms on customers' decision in using the Islamic banking services. This study employs natural experimental design with Analysis of Variance (ANOVA), and Pearson Chi-Square Test. The exploratory study also conducted to support the quantitative analysis. The results show that the religious norms among Muslims classified into two categories, i.e: traditional and contemporary group and the religious norm of the Muslim have significant affects on the decision in using the Islamic banks.
\end{abstract}

Keywords: Islamic Bank, Religious Norms, Traditional Group, Contemporary Group

\begin{abstract}
Peran Norma Religius Dalam Pemilihan Bank Syariah. Tujuan dari penelitian ini adalah untuk memberi gambaran norma religius muslim di Indonesia terhadap fatwa pengharaman bunga bank; dan mempelajari hubungan norma religius tersebut terhadap pemilihan bank. Penelitian mengaplikasikan natural experiment design dengan Analysis of Variance (ANOVA), dan Pearson Chi-Square Test. Guna mendukung analisis kuantitatif, penelitian ini juga melakukan Exploratory Study. Hasil penelitian menunjukkan bahwa norma religius muslim dapat dibagi menjadi dua kelompok, yaitu: kelompok tradisional dan kontemporer, dan norma religius mempunyai pengaruh signifikan terhadap keputusan muslim untuk menggunakan bank syariah.
\end{abstract}

Kata Kunci: Bank Islam, Norma Religius, Kelompok Tradisional, Kelompok Kontemporer

First draft: October, 4th 2014, Revision: December, 5th 2014, Accepted: December, $15^{\text {th }}$ 2014

${ }^{1}$ Pascasarjana Universitas Indonesia KajianTimur Tengah dan Islam, Jl. Salemba Raya 4, Jakarta.

Email: hardius_u@yahoo.com 


\section{Introduction}

The Islamic Bank is a banking system that operates under Islamic law, or known as 'sharia' (Haque, Jamil and Ahmad, 2007; Hassan, Chachi and Latiff, 2008; Marimuthu, Jing, Gie, Mun, and Ping, 2010; Manzoor, Aqeel and Sattar, 2010; Idris, Naziman, Januri, Asari, Muhammad, dan Jusoff, 2011). Under the Islamic law, the Islamic banks are prohibited to trade based on interest (Haron, 1997; Manzoor, et. al., 2010; Idris, et. al., 2011) which is the basic distinction between Islamic banks and conventional banks (Hassan, et. al, 2008; Manzoor, et. al, 2010). In other words, the Islamic banks adopt 'sharia compliant finance' systems, prohibiting acceptance of specific interest for loans, known as riba.

In the Second Conference in Cairo in May 1965, the Islamic Leaders, known as ulamas who gathered in the World Islamic Studies Consul has decided that there is no doubt on the prohibition of the riba (Antonio, 2001). The Concensus was also supported by the Fiqh Academy of the Muslim World League and Propagation Center, Counseling, Islamic Studies, and Fatwa, Kingdom of Saudi Arabia, and the Organization of the Islamic Conference (OIC) II in 1970, at Pakistan reached unanimously that the interest on a conventional bank contrary to Islamic law. In Indonesia, prohibitation of riba refers to fatwa Majelis Ulama Indonesia (MUI) No. 1 tahun 2004that is supported by Majlis Tarjih dan Tajdid PP Muhammadiyah No. 8 tahun 2006.

Prohibition of interest means forbids all Muslims use the services of conventional banks. Muslims would bear the sins if use a conventional bank services (Jalil dan Rahman, 2010). From this perspective, Islamic banks should be an option only for the Muslims not for the bank alternative that is often put forward as some academics, such as: Haron (1997); Memon (2007); dan Idris, et. al. (2011). Consider the law in the Islamic teachings, and the availability of Islamic banks, then the question arises: "Why the Muslim community is still not willing to stop using of conventional banking services, to further switch to Islamic banks?"

The consequence due to the fatwa issued by ulamas is the market for Islamic banking services has been growing rapidly over the past few years. Furthermore, this robust growth is expected to continue for the foreseeable future (Vayanos, Wackerbeck, Golder, and Haimari, 2008). However, it does not mean that the demand of the services of conventional banks is reduced.

In Indonesia, the Islamic banking has also been growing rapidly. Based on the Indonesian Banking Statistics, number of accounts in Islamic banks increased significantly, from 1,964,438 accounts in 2006 to 13,430,904 accounts in June 2014. In addition, Third Party Funds (TPF) has experienced a relatively high 
increasing, from 11,862 billion dollars in 2004 to 183,534 billion in 2013. Although Islamic banks in Indonesia have undergone a rapid growth in terms of the number of accounts and TPF, this phenomenon did not bring about a negative impact for conventional banks. In fact, deposits of conventional banks increased from 963,106 billion dollars in 2004 to 3,663,968 billion dollars in 2013 (Bank Indonesia, 2014). By comparing the TPF of Islamic banks and conventional banks, it shows that the proportion of TPF of Islamic banks is still relatively small, which is about 5\%. Eventhough the number of accounts in Islamic banks is increasing rapidly; it does not mean a conventional bank customers have switched to Islamic banks. Many banks customers in Indonesia hold multiple accounts. They open accounts in Islamic banks, howeeer, in the sam time they hae a conventional bank account. The condition raises the question: "Do the majority of Indonesian Muslims disbelieve the fatwa of MUI that the bank interest is forbidden (haram)?"

People generally perceive that two billion Muslims in the world adopted the same Islamic religious beliefs and practices (Azra, 2005). In fact, different opinions would not be avoided among the Muslim community across the world, because they hae differentiate in history, tradition, and culture. Since the law on the prohibition of interest is not explicitly written in the Koran, ulamas make consensus to address this critical issue that newly turns up in our modern life. At this point, sometimes there are different views among the ulamas about the meaning of 'sharia compliant finance' in the Islamic banking practices. This condition raises the question: "Do all the Indonesian Muslims believe that the bank interest is riba?"

Although ulamas have agreed on the prohibition of bank interest in the Second Conference in Cairo in May 1965, the literature reveals that some scholars still have different opinion. Islamic scholars from Modernist school of thought, such as: Fazlur Rahman, Muhammad Asad, Said al-Najjar, Sayyid Tantawi, consider that prohibitation of bank interest in the Koran are bank interest that is practiced before the Islamic era; there is a difference concept between riba and bank interest; and there is a difference between individual and institutional interest (Ahmad and Hassan, 2007). Rahman (1982) mentions that bank interest, especially in borrowing money are permitted in certain conditions.

Although the scholars mentioned about riba in conventional banks, but infact, there are still many Muslims use conventional banks. It can be assumed that indifferent opinions regarding the prohibition of interest give impact on of Muslims confidence in choosing a bank. One who believes that the interest is prohibited tend to choose Islamic banks. Nevertheless, others who believe that the bank interest is not (always) prohibited would choose conventional bank.

In the Theory of Reason Action, a normative is the subjective norms that refer 
to the perceived social pressures to perform or not to perform a certain behavior. One source of normative belief is common norms that are believed by the religious leaders' referential (Fishbein and Ajzen, 1980). Consistent with Ajzen (1985), perceived religious norms are what one perceives as the beliefs of his or her religious leader. Hence, those who are influenced by religion may regard their spiritual leaders highly when contemplating the decision (Morgan, 2004). This is the reason why this study uses the variable religious norms to reflect difference belief in the fatwa of bank interest among Muslims.

Based on the explanation above, the aims of this study are to examine Muslims' religious norms regarding to their belief in the fatwa of the prohibition of bank interest, and to investigate the effect of religius norms on customers' decision for using the Islamic banking services.

\section{Literature Review}

The main sources of the Islamic law are the Koran and Hadith. Every Muslim believes that the Koran is the word of Allah, revealed to the Prophet Muhammad. While Hadith describes the behavior of the Prophet Muhammad including about what he said, he did, he saw and he decided during his life (Gatrad and Sheikh, 2001; Padela, 2007). It was include the approval that he did not say. Thus, it was also related to all the statements that describe his physical attributes and characters (Kamali, 1991).

Since the Prophet Muhammad's death, Muslim leaders made Fatwa asa new source of the Islamic law. This is intended to deal with new issues or phenomena that arise with changes in time and culture (Hashim and Mizerski, 2010). At this point, it could appear a difference opinion among ulamas. Although Islam has provided clear directions between halal (permitted) and haram (forbidden) (Al-Qaradawi, 1999), the debates on the various issues are unavoidable because many of the current issues are not explicitly commanded or forbidden. The fact that the Koran explicitly communicated in Arabic, leads to some divergences of the interpretation, especially when it is translated into non-Arabic languages. In addition, none of the institutions has the right to issue a universal Islamic law. Hence, it is possible to observe different interpretations of the Islamic law among various Islamic institutions.

Koran has explicitly forbids Muslims to consume alcohol and or gamble in surah Al-Baqarah [2]: 219; Al-Nisa [4]: 43; Al-Maidah [5]: 93. Therefore, the rules of Koran can be understood by Muslims explicitly, and then all ulamas and Muslims in the world agreed to these rules. However, the Koran and Hadith do not explicitly arrange about organ donation and transplantation (Al-Khader, Shaheen and AlJondeby, 2003; El-Shahat, 1999, Rady and Ali, 2009). At this point appeared various 
effortsthat allows occurred differences view between ulamas. Although the Islamic Council (Senior Ulamas Commission) of Saudi Arabia stated that the Islamic rules allow the removal of organs from people who have died to save another human life (El-Shahat, 1999). However, between 1959 and 1998, there are at least 18 religious opinions that discuss the rules on organ donation and transpalansi (El-Shahat, 1999). In term of the donor's organ, Aksoy (2001) explains that there are two schools of thought in Islamic cultures, schools of thought that allow organ donation, dan the other is not allowed, because the Koran does not explain explicitly.

Same as the example above, Koran also does not explicitly prohibit bank interest. Nevertheless, it explains only about riba. Do all Muslims agree that conventional banks have to be abandoned, without a single reason? Do all Muslims agree conventional banks may be used for not taking interest given?

All Muslims agree that the riba is prohibited that it is explicitly written in the Koran (Ar-rum [30]: 39; Al-Nisa [4]: 161; Al-Imran [3]: 130; dan Al-Baqarah [2]: $275,276,278)$. However, when the riba is associated with the bank interest, debates over the concept of the riba in Koran appears. As it is mentioned before, some moderat scholars believe that the bank interest is permitted in some conditions. Rahman (1982), for instance, argued that they agreed to take extra costs or bank interestin borrowing and lending of moneyin some conditions, such as; first, the loan does not aim to exploit the weak; second, the loan does not follow practices of the pre-Islamic era; third, the interest rates is reasonable; fourth, the loan is for investment not consumption; fifth, the interest is to compensate losses to creditors due to inflation ; and sixth, the loan is for credit institutions.

This opinion certainly opposed by the traditional group, which has made a fatwa that bank interest is ribait also became the foundation for the establishment of Islamic banks. This condition indicates that there is difference belief about riba in Islam. This, of coure will give impact to the Muslim as a whole.

The social value in expenditure theory (Sheth, 1982) refers to the normative values that are held by social groups such as family, friends, or community. This definition is identical to the subjective norm in the Theory of Reason Action (Ajzen and Fishbein, 1980). In the theory of Reason Action, Ajzen and Fishbein (1980) take subjective norms as a part of behaviour factors and define it as an individual perceived social pressure to behave or not behave (Ajzen and Fishbein, 1980). The subjective norms are determined by the normative belief. This is one source of common normative beliefs that are believed by the representative religious leaders (Fishbein and Ajzen, 1980).

In social psychology, an important aspect of socio-cultural psychology is a social norm. It is defined as a way of thinking, feeling and behaving that is shared with 
their community, so they appropiate it (Cialdini, 2009). There are many important social norms in the life of individuals that determined by the culture where s/he lives. In this context, culture is defined as a set of social norms, including religious and family values and other moral beliefs that are shared by people who live in an area (Matsumoto, 2001). Therefore, the cultures impact on the thoughts, feelings, and behavior through teaching, imitation, and other forms of social transmission (Mesoudi, 2009).

This will make people depend on the influential group and their social environment. On the other hand, the culture will influence social norms and religion . It is also affect a person's social norms. Thus, religious leaders allow influencing someones' social value, subjective norm, or social norms.

Consistent with Ajzen (1985), perceived religious norms are what one perceives as the beliefs of his or her religious leader. Hence, those who are influenced by religion may regard their spiritual leaders highly when contemplating the decision (Morgan, 2004).

\section{Methods}

The populations of study are Muslims who have bank(s) account. The respondents were conditioned as to be classified into three groups - the Islamic bank customer group, the conventional bank customer group, and the Islamic and conventional bank customer group. These groups can be viewed as an environmental factor treatment in experimental design (Agung, 2011).

The customers in each group are classified into two classes based on dichotomous variable of religious norms, that are traditional group who believes in the prohibition of the bank interest and contemporary group who do not believe in the prohibition of the bank interest. Thus, the natural experimental design is a $3 \times 2$ factorial design with three groups of bank customers, i.e. Islamic banks customers, conventional banks customers, and customers of both banks; and two further groups of each, i.e. traditional group and contemporary group. Natural experimental design is used because number of respondents who only has accounts in Islamic banks is relatively small. If sample selected randomly, the customers who use a pure Islamic banks will be very little.

The sampling technique used in this study was a purposive quota. The first step is determining the number bank customers among the three groups of bank customers that are consists of 125 respondents in each group. The second step is selecting the sample with the following criteria: 1) Muslims, and 2) at least the age of 18 years. 
Data collection was carried out using a self-administered. Respondents filled out a questionnaire by themselves. However, the researcher guides them in filling out the questionnaires.

Table 1. Indicator for Construct of Religious Norms

\begin{tabular}{|c|c|c|c|}
\hline Variable & Description & Statement Items*) & Sources \\
\hline \multirow[t]{4}{*}{$\begin{array}{l}\text { Religious } \\
\text { Norms }\end{array}$} & \multirow{4}{*}{$\begin{array}{l}\text { what one } \\
\text { perceives as } \\
\text { the beliefs } \\
\text { of his or her } \\
\text { religious leader. } \\
\text { (Stephenson, et. } \\
\text { al., 2008). }\end{array}$} & $\begin{array}{l}\text { 1. Banks interest should } \\
\text { not be prohibited if it } \\
\text { does not aim to exploit } \\
\text { the weak }\end{array}$ & $\begin{array}{l}\text { Rahman } \\
(1982)\end{array}$ \\
\hline & & $\begin{array}{l}\text { 2. Banks interest should } \\
\text { not be prohibited if the } \\
\text { interest rates is reason- } \\
\text { able }\end{array}$ & $\begin{array}{l}\text { Rahman } \\
\text { (1982) }\end{array}$ \\
\hline & & $\begin{array}{l}\text { 3. Banks interest should } \\
\text { not be prohibited if it } \\
\text { for investment not con- } \\
\text { sumption }\end{array}$ & $\begin{array}{l}\text { Rahman } \\
\text { (1982) }\end{array}$ \\
\hline & & $\begin{array}{l}\text { 4. Banks interest should } \\
\text { not be prohibited if the } \\
\text { interest is to compen- } \\
\text { sate losses to creditors } \\
\text { due to inflation }\end{array}$ & $\begin{array}{l}\text { Rahman } \\
(1982)\end{array}$ \\
\hline
\end{tabular}

There are several statement items that used as Religious Norm measurements. Rahman (1982) argued that according to moderenist scholars, the extra costs or interest, especially in borrowing money is permitted in some conditions: first, the loan does not aim to exploit the weak; second, the interest rate is reasonable; third, the loan is for investment not consumption; and fourth, the interest is to compensate losses to creditors due to inflation

Therefore, the research context is banking as a credit institution. Rahman's criteria no. 5, bank interests are allowed for credit institutions that will be excluded from the statement items. Thus, statement items will be used to measure variables Religious Norms that can be seen in Table 1. Items statement to establish a religious norm variables were measured using a Likert scale between 1 (strongly disagree) and 6 (strongly agree).

Based on the average score of religious norms, customers are classified into two grouped: Traditional Customer (believe bank interest is forbidden), and Contemporary (believe bank interest are not always forbidden). The groups were done based on the average value of the score, in which: First, Traditional: smaller 
than the average score of all customers. Second, Contemporary: equal or greater than the average score of all customers.

The Analysis of Variance (ANOVA) and Pearson Chi-Square are used to test the hypotheses of religious norms influence on the selection of banks. . Thus, researcher uses SPSS version 19 in data processing. The exploratory study also used in this research in order to complete the information about the phenomena related to Islamic banking.

\section{Discussion}

After collecting the data, there were some incompleted questionnaires answered, so they should be dropped. Therefore, in order to reach the same number of bank customers, the last entry questionnaires were dropped to exceed the other groups of bank customers. Finally, the questionnaire used was 363 or 121 questionnaires for each group of bank customers.

Data processing provided descriptive statistics score of the religious norms for the overall respondents as follows: mean score $=2.91$; standard deviation $=1.43$; the minimum value $=1$; and the maximum value $=6$. Therefore, the measurements using likert scale of 1 (strongly disagree) to 6 (strongly agree), it can be stated that the average score is relatively in the middle of the measurement scale. It means that a part of respondents have a lower score than the overall average who believe that the bank interest is forbidden. And other group of respondents has an equal or higher score than the overall averagewho believe that the bank interest is not always forbidden.

Standard deviation value also strengthens the interpretation of the average score. The standard deviation indicated a religious norm scores varied among individuals, which also indicates a difference belief in bank customers towards the fatwa. The variation between individual average score of religious norms was also demonstrated by its range, with a minimum average score of 1 and maximum of 6 , which means there are customers who strongly disagree with the opinion of Moderenist schoolars. However, at the same time there are customers who strongly agree with the opinion. This result reveals that the Muslims do not always adopt a similar interpretation over the Islamic beliefs and practices.

Based on the descriptive statistics, it can be conluded that the data support the Hypothesis 1 that bank customers have different beliefs on the fatwa of prohibition of bank interest. Thus, although the MUI and the OIC has been agreed that bank interest is forbidden, but not all Muslims agree with the fatwa. This condition raises a question: "Why customers do not have the same beliefs about the fatwa?" 
This is because the prohibition of interest is not explicitly written in the Koranand the difference opinions about the fatwa of the bank interest among ulamas. The results support the statement (Al-Qaradawi, 1999) that although Islam has given clear directions between Halal and Haram, however, the debate about the issues is unavoidable because many of the issues now are not commanded or prohibited explicitly. So, it is miss perception if the people stated that two billion Muslims in the world adopt the same Islamic law in beliefs and religious practices (Azra, 2005).

If the religious norm is associated with bank customer group, the statistics show the lowest average score of the religious norms is customers of Islamic banks group (2.35), followed by the customers of both banks group (2.86) and customers of conventional bank group (3.52). This condition indicates that customers who use only Islamic bank, not all of them believe the fatwa or at least they approve one or more statements that are used to measure the variables of religious norms, which is actually contemporary thought as expressed from Rahman (1982).

Tests on the difference in parameter mean of religious norms among bank customers groups' to answer the Hypothesis 2 using ANOVA. Based on the test of the statistical hypothesis, we have the F-statistic $=20,406$ with p-value $=0.000$, so it was decided to reject $\mathrm{H}_{0}$ at level of significant $\boldsymbol{\nabla}=0.05$. It can be conclude that data support Hypothesis 2. Thus it can be stated that the parameter mean of religious norm for the customers of Islamic bank significantly different than the parameter mean of a conventional bank customers and/or the parameter mean of customers who hold two banks accounts. In other words, individuals who have the lower score of religious norm preferred to Islamic bank than conventional bank.

Furthermore, to examine differences in the mean parameters of religious norm variables between customers of Islamic bank and conventional banks, and customers of Islamic bank and customers of both banks, Tukey test was used. Based on the testing of the statistical Hypothesis 1.1 , we have the p-value $=0.000$, so it was decided to reject $\mathrm{H}_{0}$ at level of significant $\nabla=0.05$. It can be conclude that the parameter mean of religious norm for the customers of Islamic bank are significantly lower than the parameter mean of a conventional bank customers. In other words, individuals who belief the fatwa of prohibition of bank interest tended to prefer Islamic bank than conventional bank.

Meanwhile for statistical Hypothesis 1.2, it was obtained the p-value $=0.029$. This means the parameter mean of religious norm Islamic bank customers are significantly lower than customers who have accounts at both banks. These finding again showed individuals who belief the fatwa of prohibition of bank interest tended to prefer Islamic bank. 
In other words the result can be stated, the higher an individual's belief that bank interest is forbidden, the individual will tend to prefer Islamic banks, otherwise the higher the individual's belief that the interest is not always haram, the individual will tend to choose a conventional bank.

As previously explained that based on the average score of religious norms, the customer will be classified into two groups, namely: Traditional Customer Group (believe bank interest is forbidden), and Contemporary (believe bank interest is not always forbidden).

The data, shows that the Islamic banks are dominated by traditional customers, conventional banks are dominated by contemporary customers, and the group of customers who hold accounts at both banks is relatively balanced between the traditional and the contemporary customers. The results of hypothesis testing using the Pearson Chi-square Test concludes that there is a significant association between religious norms and choosing banks (Asymp sig. $=0.000)$. The statistic test revealed that the traditional group has a tendency to prefer Islamic banks, and contemporary group tend to use conventional banks. The statistical test hyphotesis also supported hyphotesis 2 that is selection of Islamic banks depends on customers' religious norms.

Nevertheless, the data showed that $32.23 \%$ customers of Islamic banks are customers who believe bank interest is not always forbidden. In contrast, $28.39 \%$ of conventional bank customers who believe banks interest is forbidden, still using a conventional bank. This condition indicates that the religious norm is not the only factors that influence the choice of the bank, but there are various other factors that could explain the phenomenon.

This situation can be explained in terms of religiosity and non-religiosity. It is possible the individual who believes fatwa of prohibition of bank interest and still using a conventional bank, due to no or less religious individuals, so that the individual is still break his/her beliefs. However, the explanation in term rational reason can not be ignored, especially because the numbers of customers who believe bank interest is not always forbidden still use Islamic banks services.

Shopping Preference Theory (Sheth, 1981) states that selection to a store is a function of the individual motivations and the availability of shopping options. Consumers will choose an outlet because the outlet offers something that meets with his/her shopping motivation. Consumers are classified as the convenience shopper, who chose the store based on the saving of time, would prefer a store based on the location of the home or workplace.

Referring to the theory, it can be stated that beyond the belief toward fatwa of 
prohibition bank interest, in selecting banks, individual also consider their needs and desires and compared with what is provided by banks. Service, price, convenience, product, competent employees, are some examples of the bank attributes that have to be considered by bank's customers in choosing the bank, as shown by previous studies (such as: Idris, et. al., 2011; Cloud and Bukhari, 2011; Hamid, et. al., 2011; and Khan, et. al., 2011).

From this perspective it can be stated that the presence of $32.23 \%$ customers of Islamic banks are the contemporary group, indicate that Islamic banks have various advantages in terms of non-religious compared conventional bank, which causes the customers choose Islamic banks. In contrast, 28.39\% traditional customers prefer conventional bank indicate the needs and desires of the customers can not be met by Islamic banks, so that they continue to use conventional banks.

Exploratory study that accompanies this quantitative analysis indicates that many customers who believe the fatwa continue to use conventional banks, because the infrastructure of Islamic banks is not in accordance with their needs and desires. Therefore, these groups typically use a conventional bank to conduct transactions, and use Islamic banks to save or investment.

Based on the analysis, it was revealed there are three groups of bank customers based on religious norms, namely: first, bank customers who believe bank interest is forbidden so convinced using conventional banks is also forbidden; second, bank customers who believe bank interest is forbidden but tolerate to use of conventional banks with specific reasons; and third, bank customers who believe bank interest is not always forbidden and so are free to use any bank.

Based on the characteristics of Islamic banks, it can be stated that Islamic banks offer the systems which is embedded positive values. Therefore, the strategy that needs to be applied in Islamic banks, is no longer just rely on the fatwa, but rather highlight the system which is based on the positive values.

Positive values in business which is embedded in Islamic banks not only be interesting for the traditional group, because these values can benefit every human being. Thus there are opportunities that the values will also appeal to contemporary groups, customers that are no or less religious and even non-Muslim groups. Besides offering positive values, Islamic banks must prepare the infrastructure in order to meet all the needs and desires of customers. In an exploratory study revealed three main factors that need to be addressed, that is: human resources, informatics system and product. That is one of the key which will make Islamic banks be able to compete with conventional banks in serving the needs and desires of customers. Furthermore, Islamic banks can also offer different services compared to conventional bank customers by using the Islamic law as a compass in carry out the business. 


\section{Conclusion}

The results showed that religious norms influenced the choice of the Islamic banks. However, the effect is not absolute because part of traditional customers does not choose Islamic banks. It shows in choosing a bank, some individuals do not just rely on his/her religious norm, but also on various other considerations. These results support the research conducted by Dusuki and Abdullah (2007) which revealed: in spite of the fact that submission to sharia has been known widely by the Muslim customers, some empirical studies find that religion is not the only reason to choose Islamic banks.

These findings also confirm the suggestion by Wilson (1995) that Islamic banks should not only consider their business just to fulfill religious obligations of the Muslims, but more significantly as a business that is always needed to win customers at the same time retaining existing customers (Dusuki and Abdullah, 2007). A similar statement was also expressed by Ahmad and Haron (2002) that Islamic banks should not rely solely on the religious factor as a strategy to attract more consumers, but should emphasize efficient service, and should look into situational factors that will determine their level of competitiveness in the future. Furthermore, Ashraf and Nurdianawati (2006) also mentions that the Islamic banking activities should no longer be regarded as an initiative to carry out a religious obligation, but significantly as the innovation needed to win the competition of customers.

Nevertheless, this study revealed that impossible for Islamic bank to regardless of religious sentiment, because basically the Islamic banks are built according to Islamic law. Obligations of religion and customers religious norm can still be relied upon as a strategy to get new customers or retain existing customers, especially for groups who believe the fatwa.

Prohibition of bank interest is fundamental difference between Islamic banks and conventional banks, but it is not the only difference. With regard to the prohibition of the bank interest, was born the concept of equity-partisipation (Hassan, et. al., 2008), profit and loss sharing system in all business conducted by Islamic banks (Haron, 1997; Idris, et. al., 2011). Islamic banks also have different characteristics from conventional banks in the correlation between the customers and the bank. In Islamic banks, the customer is a partner, not a debtor or borrower, as the practice of conventional banks (Marimuthu, et. al., 2010).

In banking practice, Islamic law also prohibits ' $g$ hahar' or speculative trading and 'maisir' or gambling (Idris, et. al., 2011). Islamic banks are also prohibited from engaging in transactions (payment or acceptance) with business related to haram products, such as: alcohol, pork trade, or gambling activities (Manzoor, et. 
al., 2010). Furthermore Islamic banks are required to conduct business and trade activities based on the principles of justice and profit halal, pay zakat, prohibit monopolies, and work for social purposes (Haron, 1997).

\section{References}

Agung, I. G. N. 2011. Cross Section and Experimental Data Analysis Using EViews. $1^{\text {st }}$ ed. Singapore: John Wiley \& Sons.

Ahmad, A. U. F. \& M.K. Hassan. 2007. Riba and Islamic Banking. Journal of Islamic Economics, Banking and Finance Vol. 3 (1), 2007: pp. 1-33.

Ahmad, N. \& S. Haron. 2002. Perceptions of Malaysian Corporate Customers Towards Islamic Banking Products and Services. International Journal of Islamic Financial Services 3(4).

Ajzen, I. \& M. Fishbein. 1980. Understanding attitudes and Predicting Social Behavior. New Jersey: Prentice Hall.

Ajzen, I. 1985. From intentions to actions: A theory of planned behavior. In J. Kuhl \& J. Beckman (Eds.), Action-control: From cognition to behavior (pp. 11-39). Heidelberg - Germany: Springer.

Al-Qardawi, Y. 1999, The Lawful and the Prohibited in Islam. 20th ed., Indianapolis: American Trust Publications.

Antonio, M. S. 2001. Bank Syariah: Dari Teori ke Praktek. Jakarta: Gema Insani Press

Asyraf, W.D. \& A. Nurdianawati. 2007. Why do Malaysian Customers patronize Islamic Banks. International Journal of Bank Marketing, 25:3, pp. 142-160.

Awan, H. M. \& K.S. Bukhari. 2010. Customer's Criteria For Selecting an Islamic Bank: Evidence From Pakistan. Journal of Islamic Marketing Vol. 2 No. 1, 2011 pp. 14-27.

Azra, A. 2005. Islamic thought: theory, concepts, and doctrines in the context of Southeast Asian Islam. In Nathan, K.S. and Kamali, M.H. (Eds), Islam in Southeast Asia: Political, Social and Strategic Challenges for the 21st Century. Singapore: Institutes of Southeast Asian Studies. pp. 2-21.

Bank Indonesia. 2014. Indonesians Banking Statistics. www.bi.go.id.

Dusuki, A.W. \& N.I. Abdullah. 2007. Why Do Malaysian Customers Patronize Islamic Banks?. International Journal Bank Marketing, 25(3).

Gatrad, A. R. \& Sheikh, A., 2001. Medical Ethics and Islam: Principles and Practice. Archives of Disease in Childhood, 84 (1), 72-75.

Hamid, Y. et.al. 2011. Factor Adopting Islamic Home Financing: A Case Study Among Consumers of Islamic Banks in Malaysia. Middle-East Journal of Scientific Research 7 (Special Issue of Diversity of Knowledge on Middle East), pp. 
$47-58$.

Haque, J. \& Ahmad. 2007. Islamic Banking: Customers Perception and its Prospect on Bank Product Selection towards Malaysian Customers Perspectives. $5^{\text {th }}$ International Islamic Finance Conference, 3-4 September, The Ritz Carlton, Kuala Lumpur, Malaysia.

Haron, S. 1997. Islamic Banking Rules and Regulations. Kuala Lumpur: Pelanduk Publications (M) Sdn Bhd.

Hashim and Mizerski, 2010. Exploring Muslim Consumers'Information Source for Fatwa rulings on Products and Behaviors. Journal of Islamic Marketing 1 (1): $37-50$.

Hassan, A. et.al. 2008. Islamic Marketing Ethics and Its Impact on Customer Satisfaction in the Islamic Banking Industry. J.KAU: Islamic Economics, Vol. 21 No. 1, pp: $23-40$.

Jalil, M. A. \& M.K. Rahman. 2010, Financial Transactions in Islamic Banking are Viable Alternatives to the Conventional Banking Transactions. International Journal of Business and Social Science Vol. 1 No. 3; December 2010

Kamali, M. H. 1991. Principles of Islamic Jurisprudence. Kuala Lumpur: International Islamic University, Malaysia.

Khan, M.S.N. et.al. 2008. Banking Behavior of Islamic Bank Customers in Bangladesh. Journal of Islamic Economics. Banking and Finance Vol. 5 No.1.

Manzoor, M. M. et.al. 2010. Factors Paving the Way towards Islamic Banking in Pakistan. World Academy of Science, Engineering and Technology 662010

Marimuthu, M. et.al. 2010. Islamic Banking: Selection Criteria and Implications. GJHSS Classification Vol 10 Issue 4.

Memon, N. A. 2007. Islamic Banking: Present and Future Challenges. Journal of Management and Social Sciences Vol. 3, No. 1, (Spring 2007), pp. 1-10 